ARTICLE

Received 11 Jan 2017 | Accepted 10 May 2017 | Published 20 Jun 2017

DOI: $10.1057 /$ palcomms.2017.52

OPEN

\title{
Ideas, structures, and the (un)conventional politics of minority rights in Romania and Ukraine
}

Egor Fedotov ${ }^{1}$

ABSTRACT This article uses a paired comparison of ethnic politics in postcommunist Romania and post-Soviet Ukraine to explore the example of language policy implementation, empirically speaking. It argues that the (variable) behaviours of linguistic minority elites-the Hungarians in Romania and the Russophones in Ukraine-are driven by elites' ideas (or ideational elements), theoretically speaking. In Romania, a politics of interethnic compromise and the quid pro quo gained the upper hand. In Ukraine, a politics of confrontation carried the day. In these two cases, the divergence-in behavioural terms-had had far-reaching political consequences, the latter affecting the level of cooperation and the amount of trust amongst the ethnic groups. These findings enrich our understanding of the behaviour of these particular groups in politics and of the policies toward them.

\footnotetext{
${ }^{1}$ Europe House, University of Pannonia, Köszeg, Hungary Correspondence: (e-mail: efedotov31@gmail.com)
} 


\section{Introduction}

ommunism's fall in Eastern Europe in 1989 served to raise political tensions between ethno-linguistic groups, as national minorities in some newly emergent (postcommunist) states pressed for the protection of "their" rights (for example, Brubaker, 1996; Csergo, 2007). At the same time, however, more than 25 years since the fall of communism, political relations between ethno-linguistic groups in some states (for example, Ukraine) remain strained; whereas in others (for example, Romania) these relations markedly improved. In effect, one sees marked differences in the scope of sanctioned language use, formally so, by the state. Why? The present article sets itself the task to examine in detail evolving (political) relations between Russian speakers and Ukrainian speakers in Ukraine and between ethnic Hungarians and ethnic Romanians in Romania in order to shed light on the divergent policy outcomes in these states.

In terms of its methodological goals, this article gives pride of place to the behaviour of vulnerable or disadvantaged groups themselves-like national minorities. This focus stands in sharp contrast to that in the existing literature on ethnic politics and the role of international norms in world politics, say, that of the norm of language rights for national minorities. ${ }^{1}$ The major reason is that students of the above tend to place emphasis on exogenous factors, like leverage, to explain either the behaviour of vulnerable or disadvantaged groups (like national minorities) or policy towards them. For example, the large body of empirical research on human rights protection has arguably conclusively shown that the role of transnational activist networks can be key to the states' honouring of those rights (Klotz, 1995; Keck and Sikkink, 1998; Risse et al., 2013). Not unrelatedly, the growing literature on ethnic politics proper has foregrounded the role of either international organizations or the minorities' kin states in attempting to elucidate policy or behaviour (Van Houten, 1998; Kelley, 2004; Jenne, 2007). The upshot has been that students of norms and/or ethnic politics failed to give due attention to the potentially politically significant behaviour of vulnerable or disadvantaged groups themselves, say, labour migrants (cf. Gurowitz, 1999: 432). Yet the analysis, presented here, showson the example of language politics in Romania and Ukrainethat the strategic choices or decisions of vulnerable or disadvantaged groups, like national minorities, often carry significant political consequences. (Specifically, in the Romania and Ukraine cases, these decisions can affect crucially political trust among the ethno-linguistic groups and the extent of cooperation between these groups in politics.) ${ }^{2}$

In Ukraine, the politics of confrontation between Russian speakers and Ukrainian speakers gained the upper hand. By contrast, in Romania, this occurred for the politics of interethnic compromise and a quid pro quo, among the two main ethnolinguistic groups: Hungarians and Romanians. The difference between a politics of compromise and that of confrontation is apparent, in Romania and Ukraine, on both the intra-national and national levels. That said, in Romania the above divergence has been more pronounced-and politically significant-than in Ukraine. Correspondingly, the evidence in the former regarding the causal role of the strategic choices or decisions by linguistic minority elites is more conclusive than in the latter. Empirical analyses are nuanced. However, they're not a study in history! My larger theoretical point, which is how linguistic minority elites act in politics matters, stands, regardless of the temporal scope of empirical analyses.

Stated in other terms, this article argues that we ought to endogenize the political environment in which ethnic minority elites strive for power and an efficient policy of minority rights protection to explain why policy towards some vulnerable or disadvantaged groups (like national minorities) can be variably carried out.
The article is in four parts. First, I present the theoretical framework for the study of ethnic politics in Romania and Ukraine. Next, I provide an analytical summary of the evidence. The third and largest section presents the results of empirical research. The concluding section summarizes the main empirical findings and suggests several implications.

\section{Ideas, structural ambiguity and human action}

Following political scientist Parsons's (2007) use of the term, I understand by "structures" an exogenously given obstacle course which channels actors towards certain behaviours. Thus structural explanation or theory unpacks the variable behaviour of actors by looking at their position in the particular obstacle course-that is composed of some salient apparent resources and constraints, say, leverage (Jenne, 2007). In this way, structural explanation or theory predicts that those actors who share the (largely) similar position would behave in (largely) similar ways (Moore, 1966; Bates, 1981; Mearsheimer, 1990). This is because, as Parsons (2007: 13) theorizes, structural claims "require micro-foundations in objective rationality", which is conceived of as the mechanism which links the variation in (human) action with that in structural conditions facing elites.

Following sociologist Swidler (1986), I understand by "ideas" a tool kit or a repertoire composed of assumption-based lines of action by which actors aim to achieve (often) similar ends but not necessarily by the same means. (In the present analysis "ends" are the pursuit of power and better policy performance by elites while "means" are either a politics of interethnic compromise or that of confrontation.) In essence, ideational explanation or theory postulates that any form of leverage is underdetermined for the behaviour of elites. This is because elites lack in foresight (a hardly controversial claim!) regarding the ways in which their future behaviours would ultimately play out in actuality.

It is a short step then to accept prima facie the proposition that because structural ambiguity can in principle be consequential for the behaviour of elites; the latter find it necessary to rely on assumptions or interpretative frames in regard to how to proceed (Biernacki, 1995). Hence the biggest challenge which a structuralist argument can pose to its ideationalist counterpart is that the given distribution of exogenously-given resources and constraints might well strengthen (or reinforce) already-existent behaviours of elites. But, so an ideationalist argument holds, the above incentives and constraints need not incline elites to act in particular ways.

One possibility that suggests itself regarding the ways in which actors strive for the realization of particular ends is that there may well be more than just one such way (for example, Dobbin, 1994; Berman, 1998; Blyth, 2003). In this case, the obstacle coursecomposed of incentives and constraints-leaves to actors a fairly large room of maneuver. So actors rely on their assumptions or cognitive priors first and foremost in attempting to choose, and alight on, an optimal or satisficing course of action. In this way the behaviour of elites is still, so to speak, subordinate to "their" resources and constraints, considering that these elites aim to assemble or think through the ways in which they can "best" negotiate the obstacle course made up of those resources and constraints. Nevertheless, we can argue that the range of possible ways in which the above would be likely to occur is fairly large. This is because, as Parsons $(2007,101)$ cogently argues, "the complex assumptions [might] lie behind even the simplest political actions" (cf. Berk, 1994). Thus, following others, Parsons calls variable patterns of action, as we have theorized them in the foregoing, characteristic of the presence and operationability of "multiple rationalities" (see Hollis and Lukes, 1982). In turn, in 
his (2007, chapter 4) vocabulary, he substitutes for the latter a more explicit language, which is a-rationality.

Another possibility that suggests itself regarding action is that actors can dispense with rationality as such (e.g., Reddy, 1987; Legro, 1997: 51). That is, it becomes difficult, nay, impossible, to make sense of the behaviour of elites by taking into account the most salient apparent exogenously-given resources and constraints (such as domestic and/or international leverage). The main reason for this is that actors do no less than "misrepresent or ignore even salient structural [conditions]" (Parsons, 2007: 102). In this case, we can make the strongest case for the autonomous influence of ideas on the behaviour of elites. This is because, as Parsons (2007: 101) puts it, "By breaking with rationality ideational claims concede less to logics of position". Or, to put it otherwise, the behavioural strategies of elites are deeply influenced by the latter's assumptions or interpretative frames.

It must be stressed here that irrationality and a-rationality are synthetic. That is to say, actors can have their own organizing principles.

The macrosociological analysis of human behaviour presented here inexorably opens itself to a charge of historical inadequacy. I submit that critics of the comparative analysis, of human action, miss the point of such analysis, which is to explore commonalities across diverse sets of empirical cases without sacrificing attention to detail (see, for example, Skocpol, 1979; Goldstone, 1991)! As Waters (1995: 522, emphasis added) argues, ambiguities surrounding the logic of comparative analysis shouldn't belie "significance or the very real nature of the process".

\section{Historical backdrop}

Romania and Ukraine both have a history of burdened interethnic relations. Ukraine's history of interethnic relations is burdened by the colossal subjugation of Ukrainians by Russians on levels of language, education, culture and "ethnos". Therefore, there emerged "the dilution of markers of Ukrainian identity" (Wolczuk, 2000: 672). Romania's history of interethnic relations is burdened by the memory of Hungarians about their being forced by Romanians to assimilate into the Romanian society, particularly in the second half of the twentieth century. So there arose the notion that "Hungarian nationalism was ... retrograde and irredentist" (Andriescu, 2009: 112). Benedict Anderson (1983) reminds us of the salience of memory processes to resurgent (Ukrainian or Romanian) nationalisms.

Ethnicity as a sociological category is constructed. In other words, groups sharing a given cultural identity re-negotiate the terms on which they affront "the outside world", the upshot being differing allegiances to one's own ethnicity (Cornell and Hartmann, 2007). Thus it follows that identity politics cannot be reduced to elites' action per se.

\section{The evidence}

No theory has complete explanatory purchase over the empirical reality, and the theory elaborated here is no exception to this statement or conviction. That being said, the above heuristic devices (that is, a-rationality and irrationality) can shed light on the behavioural strategies of linguistic minority elites in the Romania and Ukraine cases.

In the Romania case, it is possible, methodologically speaking, to show that the behaviours of moderate ethnic minority elites (Hungarians, remember) are unequivocally a-rational. This follows from the fact that a politics of interethnic compromise and the quid pro quo brought about the sought-after, lasting changes in Romania's (language) policy toward Hungarians. Furthermore, this politics served to redound to the power of those elites who pursued it. What is more, doing thus also served to better the political image or reputation of the mainstream Hungarian elites in Romania.

Likewise, we can make the strongest case-in methodological terms-for the case that the behaviours of radical Hungarian elites in Romania are irrational. This follows from the fact that a politics of disengagement or quasi-confrontation made it more difficult both for the moderate and radical-cum-marginalized Hungarian elites in Romania to have changes in the policy toward Hungarians implemented-which these all elites strived for. Furthermore, radicalism among some Hungarian elites in Romania served to diminish the political support for these elites in the Hungarian minority itself. What is more, radical Hungarian elites in Romania sustained heavy losses in regards to their political image or reputation, which had been damaged arguably beyond repair (this is both from the perspective of mainstream Hungarian elites and Romanians across the board).

Lastly, speaking of the substantive assumptions or interpretative frames, the moderate Hungarian elites in Romania saw any form of autonomy, for the Hungarian minority, as unrealistic. So, these elites argued in favour of substituting a small-steps-policy aimed at addressing the immediate concerns of Hungarians for the above (long-term) goal. In contrast, the radical Hungarian elites in Romania argued in favour of enforcing the policy aimed at granting autonomy to the Hungarian minority on the regional level by internationalizing the language dispute. It is no exaggeration to say that these elites did thus because they harbored distrust for the presumed goodwill of the Romanian political elite.

According to the most recent census of the population in Romania, the Hungarian minority comprises 6.5 percent of this population (http://www.recensamantromania.ro/wp-content/ uploads/2013/07/sR_Tab_8.xls, accessed 9 June 2017). Further, the Hungarian minority is settled predominantly in Transylvania (central Romania).

Unlike the Romania case, the Ukraine case is less conclusive regarding whether the behavioural strategies of radical Russianspeaking elites in Ukraine are a-rational or irrational. For example, as will be evident in the empirical analysis, a confrontational politics, whereby mainstream Russian-speaking elites gave little (if any) regard for the salient apparent needs of Ukrainian speakers, redounded to the power of these elites and the prima facie improvement in Ukraine's language policy toward national minorities (and, particularly, Russian speakers). At the same time, however, it will be also evident in the analysis that the above politics made it more difficult for the Russian-speaking elite at large to seek after power and better policy performance. The latter is so because a politics of confrontation served to strengthen the resolve of the Ukrainian-speaking elites to resist the inroads made by the Russian speakers in the issue-area of the protection of language rights for national minorities (and, particularly, Russian speakers). In this way the evidence in the Ukraine case, taken individually, is mixed.

Further, unlike the cleavage in ethnic minority politics proper in Romania, the similar cleavage in language politics among the Russian-speaking elites in Ukraine is hardly pronounced. Thus it does not appear to be possible, methodologically speaking, to characterize the alternate, consensus-marked courses of action in Ukraine as being a-rational or irrational, that is, if we consider the Ukraine case separately.

Lastly, speaking of the assumptions or interpretative frames which elites in Ukraine brought to bear on the politics of language, the Russian-speaking elite at large saw the language dispute in zero-sum terms. (That is, for this elite, only one side could, so to speak, nationalize the other.) In contrast, the marginal Russian-speaking elites in Ukraine, who proposed 
the alternate (consensus-marked) courses of action, placed emphasis on the immediate concerns of Russian speakers rather than the politics of language per se.

According to the most recent census of the population in Ukraine, Russian speakers comprise 29.6 percent of this population (http://2001.ukrcensus.gov.ua/eng/, accessed 9 June 2017). Further, Russian speakers are settled predominantly in the eastern and southern parts of Ukraine.

\section{Case selection}

There are several reasons why a comparison of language politics in Romania and Ukraine seems to be compelling. One, in both these states protection of (language) rights for national minorities is contested. So, this fact alone renders Romania and Ukraine prima facie comparable. Further, in both Romania and Ukraine there is the relative scarcity of wealth, which arguably makes political compromises between the ethno-linguistic groups more difficult to achieve. Hence, if interethnic compromises between some ethno-linguistic groups in the above states can be achieved (the relative scarcity of wealth notwithstanding), then we would have more reason to believe that the "wealth" factor need not pose an insuperable obstacle to inter-linguistic reconciliation between the ethno-linguistic groups. Finally, Romania and Ukraine showcase the high degree of variation in the value of dependent and independent variables, which permits me to make the following, unusually strong claim. Namely, this claim is that a politics of interethnic compromise has the larger chance to bring about the sought-after, lasting changes in state policies toward national minorities than does that of confrontation. ${ }^{3}$ Consequently, linguistic minority groups shall draw upon languages use on the ground, freely so.

Romania and Ukraine are contrasting cases. The parameters staked out by them don't militate against any other baseline.

\section{Note on the data}

The empirical analyses, presented below, draw upon a variety of sources, which include the primary and secondary ones. The primary sources include occasional official documentation and the interviews conducted by the author in Romania, Ukraine and Hungary. ${ }^{4}$ The secondary sources include the area literature and press reports that are accessed predominantly at Factiva and Lexis-Nexis Academic. (In turn, the interview material aims to prop up rather than inform the empirical analyses throughout.)

The case of managing ethnic politics: Evidence from Romania In brief, the mainstream Hungarian elites in Romania pursued a politics of interethnic compromise and the quid pro quo in a setting that had been highly susceptible to interethnic conflict in the arena of politics. Yet these elites managed to effect the soughtafter, lasting changes in Romania's (language) policy towards the Hungarian minority. ${ }^{5}$

Phase one: In isolation. In 1989, the Romanian people overthrew the communist dictatorship in a bloody revolution that had been sparked by Calvinist bishop László Tőkés (who was himself Hungarian). The revolutionary unity of purpose notwithstanding, the relations between Romanians and Hungarians had markedly worsened by March 1990 when interethnic violence erupted in the Transylvanian town of Târgu-Mureş-over unmixing of bilingual education (which itself was the legacy of Communism) (Brubaker et al., 2006: 127-36). Given this, the caretaker government, led by former Communist Ion Iliescu, reneged on its promise to the Hungarian minority (made at the time of the revolutionary euphoria) to grant it special (or collective) rights (Horváth, 2002:
23-24) - by which the government meant in one way or another some variant of autonomy, for the Hungarian minority.

The above violence-which had left several people dead (and hundreds injured)-served to strengthen or reinforce the (already-existent) political conviction ${ }^{6}$ amongst the mainstream Hungarian elites, grouped under the umbrella of the Democratic Union of Hungarians in Romania (UDMR), with regard to the inexpediency of seeking after any form of autonomy, for the Hungarian minority, in a political setting that had been prone to encouraging inter-ethnic animosity or hatred. ${ }^{7}$ Yet, not all Hungarian elites in Romania took such a position in politics. For instance, Tókés, who had been at the time the honorary president of UDMR, called-shortly after the March-1990-events -on the actual Hungarian leadership to take a "tougher" position on the question of the granting of collective-or "special" - rights, for the Hungarian minority. ${ }^{8}$

In 1992 Iliescu was reelected President of Romania. (The first parliamentary and presidential elections in Romania were held in 1990.) Subsequently, the Iliescu-led government or coalition allied itself with the several nationalist parties which unleashed a witch hunt against the Hungarian minority (see, for instance, below; Brubaker et al., 2006, passim).

The UDMR then made a number of "defensive moves". Four of such moves can be highlighted here.

Firstly, the UDMR called-in the wake of the above (1992) elections-for the granting of some form of autonomy, for the Hungarian minority, in the Harghita and Covasna counties, both of which are Hungarian-inhabited (that is, Romanians comprise the minority of the local population there). Secondly, it sent to the Council of Europe (CE) in Strasbourg-on the eve of Romania's accession to this body, in 1993-the memorandum, which highlighted inter alia the following demands of the Hungarian minority at large: the re-opening of the historic Hungarian university in Cluj in Transylvania; the teaching of the history and the geography in secondary-or post-kindergarten-education in the Hungarian language, rather than Romanian; and the appointment of Hungarians, rather than Romanians, in the capacity of prefects (the ones who oversee the implementation of laws on the regional level) in the several (Hungarian-inhabited) counties. Thirdly, the Hungarian minority at large was compelled, in 1995-1996, to fight against a certain education law that put restrictions on the use of the Hungarian language in university entrance examinations. Fourthly, the UDMR created in 1995 the supra-regional council-composed of the mayoral authorities-to improve the state of the protection of (language) rights for the Hungarian minority. ${ }^{9}$

To conclude, ethnic minority elites in Romania found themselves to be in a difficult political position after the fall of Communism, in which they had been thoroughly isolated even among the ranks of the opposition political parties. ${ }^{10}$ Hence, the mainstream Hungarian elites in Romania had, arguably, no other political choice than to beat the drums of justice. Tangible aspects of languages use remained elusive.

Phase two: The UDMR enters government. In fall 1996 Romanians cheered the victory of the Democratic Conventionled by Emil Constantinescu-in the parliamentary and presidential elections. After the above elections, the winning parties left the door open to the UDMR's joining of the government. (The winning parties were both historic and newly-founded ones.) The UDMR seized an opportunity to enter government. In this way, the mainstream Romanian parties acquired both the parliamentary majority ${ }^{11}$ and the accolades from the European Union (EU).

Head of UDMR Béla Markó called the Hungarians' joining of the government "historic". ${ }^{12}$ At the same time, however, Tőkés- 
and those assembled around him-were sceptical about the presumed benefits of interethnic collaboration. So Tőkés dismissed the criticisms directed against him in the UDMR as nothing new. ${ }^{13}$ In addition, he stressed that he never went against his own convictions. ${ }^{14}$ Quite importantly-upon entering the government-the UDMR laid aside its demands for some form of autonomy, for the Hungarian minority. According to one informed observer (who was from Hungary), had the mainstream Hungarian elites in Romania not done the above, they would have most certainly continued to be shunned, by Romanian political elites in general. ${ }^{15}$

Once in the government, the UDMR was able to appoint ethnic Hungarians in the capacity of prefects in three counties. ${ }^{16}$ Further, the government made several emergency steps aimed at legalizing the use of the Hungarian language at all the levels of education as well as on the level of the regional authorities. (The above steps had been made through the issuance of special government decrees which obviated the need, on the temporary basis, to pass the minority-rights laws proper.) Nevertheless, even decrees as such ran into the opposition in the mainstream Romanian political elite. ${ }^{17}$ The UDMR then threatened, in 1997 (and, again, in 1998), to leave the government. The most urgent demand of the mainstream Hungarian elites at the time, was unmixing of the Babeş-Bolyai University in two separate institutions (Gallagher, 1995: 56).

In fall 1998, the parliamentary committee on educational reforms ruled against the establishment of state-funded Hungarian-language universities in Romania. ${ }^{18}$ Instead it permitted the creation of study groups-to be held in the Hungarian languagein so-called multicultural universities, like the Babeş-Bolyai University (Horváth, 2002: 99). The UDMR, however, was not satisfied with the above proposal. (So it threatened anew to leave the government.) Constantinescu then made the last-ditch attempt to keep the coalition intact by proposing to the UDMR the establishment of a bilingual Hungarian-German university in lieu of the Hungarian-language one. ${ }^{19}$ (The above proposal found little support amongst the Hungarians and the politicallymarginal Germans.) The UDMR remained in the governmentthe above notwithstanding. Tókés continued, however, to criticize the Hungarians' participation in the government. ${ }^{20}$

The UDMR ultimately managed to secure political support required for the creation of Hungarian-language departments in multicultural universities. ${ }^{21}$ Further, the government in part institutionalized some earlier emergency ordinances to protect the (language) rights of the Hungarian minority (Csergo, 2002: 23).

To conclude, a politics of interethnic compromise and the quid pro quo pursued by the mainstream ethnic minority elites in Romania helped to bring about the sought-after changes or some of them in Romania's (language) policy toward Hungarians and, perhaps, other national minorities as well. Further, the above politics helped to improve the image of UDMR; for, it was, arguably, a most reliable grouping in the fraction-ridden Constantinescu-led coalition which witnessed the turn-over of three premiers. In contrast, a politics of inter-ethnic disengagement advocated and pursued by the marginalized ethnic minority elites in Romania held out the promise of plunging the Hungarian political leadership into continued isolation. Furthermore, the above politics held out the prospect of complicating the coming to power by the anti-communist alliance. State sanctioned control over languages use became a possibility.

Sociological change in Romanian polity owing to a certain politics comes into view.

Phase three: The UDMR seen as serious player. In 2000, Romania held new parliamentary and presidential elections. In these elections, the ruling Romanian political parties suffered a resounding defeat at the hands of the Social Democratic Party (PSD) of Iliescu and those of the ultra-nationalist Greater Romania Party (PRM). In the second run-off in the presidential elections Iliescu had beat the ultra-nationalist Vadim Tudor who captured a shocking 33.2 percent of vote.

The victorious PSD then extended an olive branch to the UDMR in the hope to obtain the latter's support in the parliament. For its part, the UDMR forewent the possibility to press for the Hungarians' joining of the government proper. (It did so because it decided that outside a coalitional arrangement the powers-that-be would be more willing to meet the demands of the Hungarian political leadership). ${ }^{22}$ Markó called the political position of Tôkés in the above elections, whereby Tőkés urged some Hungarian leaders in the UDMR not to be listed on the common ticket, "schizophrenic". ${ }^{23}$ In turn, Tókés argued that the pact or parliamentary alliance between the UDMR and PSD was "schizophrenic". ${ }^{24}$

Between 2000 and 2004 (when the new elections in Romania had been held), the Romanian ruling elite did inter alia the following. Firstly, the parliament passed the law which legalized the use of the Hungarian language on the level of the regional authorities in areas in which the Hungarian minority comprised more than 20 percent of the local population. Secondly, it opened the door to the restitution of the church and school properties that had been taken away from the Hungarian minority during Communism. ${ }^{25}$ Thirdly, the Romanian ruling elite permitted the founding of the private Sapientia University as well as increased the number of hours and of the extent of Hungarian-language education at the Babeş-Bolyai University. Fourthly, the government repealed the earlier laws-passed during the previous Iliescu administration-which outlawed the use of foreign (read: Hungarian) national paraphernalia such as flags on the territory of Romania. In light of the above changes in Romania's (language) policy toward the Hungarian minority, the PRM - "a lonely voice" in the parliament ${ }^{26}$-threatened to impeach Iliescu, but to no avail.

In the meantime, Hungary adopted, in 2001, the so-called status law on Magyars that had been meant to give them (modest) financial assistance both inside and outside Hungary (for example, discounts for the travel and educational stipends) (Deets and Stroschein, 2005: 299-301). The row between Hungary and Romania over the implementation of the status law in Romania ensued. The UDMR resolutely rejected the possible view according to which the mainstream Hungarian elite in Romania was partial towards the diplomatic dispute over the status law's enforcement in Romania. Instead it called on both Hungary and Romania to resort to diplomacy, so that the genie would not be let escape from the bottle. ${ }^{27}$ Specifically, Markó argued that, for him personally, the good relations between Romanians and Hungarians both inside and outside of Romania, were the priority over the status law per se. ${ }^{28}$ At the same time, however, some Hungarian elites in Romania considered otherwise. In particular, these elites considered themselves to be empowered due to the active political support from Hungary, and so they threatened to bolt the Hungarian alliance which they had accused of acting as the "voting machine". ${ }^{29}$ Subsequently, the above rebellion among the ranks of the Hungarian political elite led, in 2003, to the expulsion of Tökés in the capacity of the honorary president of UDMR. (The UDMR simply abolished the above post.) For his part, Markó became re-elected head of UDMR in the same year with a lop-sided 326-368 vote. Markó had been elected time and again head of UDMR in the first instance because of his argument that "Our mission is not to engage in polemic $[\mathrm{s}]{ }^{30}{ }^{30}$ Hungary-as the kin state of ethnic Hungarians in Romania-exerted a powerful influence on 
Romania's Hungarian minority elites as these elites struggled to gain control over policy.

In 2003 the government oversaw the enactment of Constitutional amendments which, inter alia, legalized (at least in the sense of de jure) the use of the Hungarian language in courts in areas in which the Hungarian minority composed more than 20 percent of the local population. Further, in the period of the collaboration between the PSD and UDMR the latter had benefited quite significantly in terms of addressing the issueareas of the local or regional character. Given the above collaboration (between the PSD and UDMR), one very highranking Romanian political leader called the UDMR "a serious party" for which the parliamentary alliance-with the PSD-had been the quasi-test, which the UDMR stood. ${ }^{31}$

To conclude, if we look at incentives and constraints facing UDMR, then we should infer that mainstream ethnic elites in Romania were expected to ratchet up their demands for autonomy, for the Hungarian minority. (In part, the above follows from the fact that PSD became increasingly dependent on UDMR to pass any legislation, especially since after 2003 when a minor Romanian party withdrew its political support for PSD. In addition, the Hungarians were offered "support" by Hungary.) Despite these latter factors, mainstream ethnic minority elites in Romania engaged in low key cooperative efforts in the hope (which vindicated itself) to effect the sought-after, far-reaching changes in Romania's (language) policy toward the Hungarian minority. Practice of languages use grew prevalent.

Phase four: Ethnic politics-A normalcy. The 2004 elections led to the victory of Traian Băsescu, of the Democratic Party (PD), who became the President of Romania. For its part, the UDMR was wary about the prospect of entering the government with its erstwhile allies in the 1996-2000 coalition. Nevertheless, it did so. In addition, the mainstream Hungarian elites in Romania faced an emergence of the several minor Hungarian parties and movements which positioned themselves, in minority politics proper, as the alternative to the UDMR.

As if to adumbrate the apprehensions of the UDMR, the government voiced opposition to the bill on cultural autonomyfor the Hungarian minority - which the Hungarian alliance had tried to put on the parliament's agenda, for the first time after entering government in 1996, in 2005. Those Hungarian elites in Romania, who were assembled around Tôkés, denounced the above bill because it peddled, in their view, a fake form of autonomy, for the Hungarian minority. ${ }^{32}$ So these elites called on the European Parliament (EP), in the hope to put Romania under external pressure, to delay the latter's planned accession to the EU in $2007 .{ }^{33}$

In the meantime, the governing and opposition parties "joined forces" to derail the UDMR's bill on cultural autonomy, for the Hungarian minority. ${ }^{34}$ The PD in particular issued an ultimatum that it would not support the above bill unless the future decisions by the regional authorities on the question of culture could be vetoed by special committees. ${ }^{35}$ Markó flatly rejected this deal, and argued that the UDMR had been "deceived" by its Romanian partners. ${ }^{36}$ At the same time, however, he minced no words regarding the fact that protection of language rights for the Hungarian minority was by and large secured. ${ }^{37}$ (The UDMR's bill on cultural autonomy, for the Hungarian minority, never took off the ground-under the temporal scope of this analysis.)

While Romania geared towards the EU accession, the radical Hungarian elites in Romania held, or threatened to hold, the unofficial referenda in Transylvania on territorial autonomy, for the Hungarian minority. ${ }^{38}$ Relatedly, the 2007 EP elections galvanized Tókés, who ran in these elections successfully as the
Independent. As if to preempt the radicals' challenge, the UDMR established in 2007 the Council for Cultural Autonomy. This time, Tókés's rejoinder was that the question of autonomy, for the Hungarian minority, cropped up in the UDMR's program in every elections though not between them. ${ }^{39}$ Instead, for him, the above question had had to be put on the domestic political agenda no less than seventeen years earlier, that is, just shortly after the 1989 revolution. ${ }^{40}$

In this way, the demarcation line between the moderate and radical Hungarian elites in Romania remained salient. In a personal interview with the author, one senior UDMR official put it in following terms.

[What those who call for autonomy tout court] deliberately lay aside is that-regardless of any referenda, regardless of any street movement, and regardless of whatever else one can imagine-any bill or law on autonomy, on selfdetermination, or on self-governance, has to be voted on in the Romanian parliament, because we live in Romania.... [Not doing the latter] is like when you wish to build a big and beautiful house, and, firstly, you build a chimney for your house. Yet it is not possible, in this way, to place the chimney up in the air. ${ }^{41}$

Following the 2008 elections, the UDMR went into opposition. However, given the break-up of the grand pan-Romanian coalition in fall 2009, the UDMR was invited to enter government again-in an ethnic politics "as always". (The above pattern repeated itself in several years-in 2014.)

To conclude, the radical Hungarian elites in Romania persistently pressed the possibility of implementing policy measures that proved to be unrealizable (under the temporal scope of the present analysis). Furthermore, these elites lost whatever prestige they had had at the time of the 1989 revolution. ${ }^{42}$ Relatedly, they sustained significant losses in terms of power. (On this score, one structuralist account concludes that Tőkés "was sidelined by the late 1990s") (Jenne, 2007: 121). So no Romanian political party was, at any time, willing to consider the radicals' policy proposals seriously. For its part, the EP was, at best, lukewarm towards the above proposals. ${ }^{43}$ Languages use became part of the status quo.

Macrosociological developments occur.

In what follows next we examine the evidence from Ukraine, which showcases the main lines of inter-linguistic conflict in politics in the reverse order, to wit, what has been "conventional" in Romania is "unconventional" in Ukraine, and what has been "unconventional" in Romania is "conventional" in Ukraine.

\section{The case of entrenching language politics: Evidence from Ukraine}

In brief, the mainstream Russian-speaking elites in Ukraine pursued a politics of confrontation in a setting that was, arguably, favourable to the emergence of schisms based on the linguistic factor. So these elites lent a hand to the entrenchment of language politics in Ukraine, which turned out to be a pyrrhic victory-for them. ${ }^{44}$

Phase one: "All Quiet on the eastern front"45. Following the independence of the Ukrainian state in $1991,{ }^{46}$ the first two parliaments in (post-Soviet) Ukraine had been occupied by the centrist (or amorphous) coalitions (cf. Shevel, 2009: 280). The central aim of these coalitions at the time was the creation of the Ukrainian state as such (Wilson, 1996). Now given the fact that Russian speakers in Ukraine had had the guarantees of the Soviet Ukrainian state during Communism - that the protection of their 
linguistic rights would be at all times honoured (see, for example, Laitin, 1998, chapter 3)-the language conflict in politics in a postSoviet Ukraine, did not emerge until a decade or so after the collapse of the communist regime. Unlike the Hungarians in postcommunist Romania-who struggled to restore the particular extent of the protection of their linguistic rights, which had been commandeered by communists-the Russian speakers in Ukraine had had to wait for that moment when they perceived that the prerogatives which were available for them during Communism, appeared to be threatened. ${ }^{47}$ As an informed anonymous interview subject expressed the above dynamic, the Russian-speaking elites in an independent Ukraine had had the wait-and-see attitude towards the protection of language rights for Russian speakers. ${ }^{48}$

However, whenever since the fall of Communism the Russianspeaking elites in Ukraine saw an opportunity to press the rights agenda, they did thus. So, in the 1994 parliamentary and presidential elections the regional authorities in the cities of Donetsk and Luhansk in eastern Ukraine held the unofficial referenda on granting the Russian language official status. ${ }^{49}$ (The 1989 language law in Ukraine laid down the sole official status of the Ukrainian language.) (http://gazeta.zn.ua/LAW/zakon_o_ yazyke_osnovy_yazykovoy_politiki_ili_zasada.html, accessed $\overline{9}$ June 2017). Further, the authorities in the Crimea were locked, in the early 1990s, in a struggle with the Ukrainian national government over devolution of autonomy in the peninsular (see, for example, Stewart, 2001). No doubt the autonomists in the Crimea, at that time, looked to Russia as a protectionist state.

In the elections in 1994, Leonid Kuchma was elected President of Ukraine. While campaigning for election, Kuchma promised to the Russian-speaking constituencies that as President he would strive for having two official languages in Ukraine, namely Ukrainian and Russian. ${ }^{50}$ Once elected President, however, Kuchma backpedaled, and set in motion what later would be called in popular historiography opportunistic state-building. The Ukrainian nationalists' indignation-regarding Kuchma's ostensibly pro-Russian electoral promises-had been the main reason for why he did the above (see, for example, Arel, 1995: 172). Subsequently, Kuchma occasionally went through the motions to placate the Russian-speaking constituencies (see, for example, Stepanenko, 2003: 122).

In 1996 the Kuchma-led government adopted the Ukrainian Constitution. The Communist Party opposed the adoption of this constitution. To break the Communists' resistance, Kuchma made a veiled threat to put the adoption of the Constitution on referendum. The Communists caved in, and so the version of the constitution-which had been favoured by Kuchma-was passed. The above Constitution re-asserted the status of the Ukrainian language as the country's sole official language, and guaranteed the Russian language all-round protection though without official status for it. ${ }^{51}$

To conclude, the Russian-speaking elites in Ukraine found themselves to be deprived of any legal means to press the possibility of de jure bi-lingualism. ${ }^{52}$ Languages use showed signs of inertia.

Phase two: The sudden availability of "European" leverage. Following the 1994 elections, the Ukrainian education ministry began to promote the creeping Ukrainization. In this way, the Russian-speaking elites in Ukraine found themselves in limbo as to how to call for de jure bi-lingualism.

At this point, however, the Ukrainian foreign ministry put its signature on a certain European treaty, which was the European Charter for Regional or Minority Languages (ECRML), of the CE -the Strasbourg-based pan-European organization for the protection of human rights. (The ECRML had been signed by
Ukraine in 1996, which was also the formal "deadline" for the treaty's ratification in Ukraine.) Perhaps surprisingly, the Ukrainian governing elites apparently gave remarkably little thought to how Ukraine's signature and (possible) ratification of the ECRML would affect the latter's language policy toward national minorities (and, particularly, Russian speakers). ${ }^{53}$ The radical Russian-speaking elites in Ukraine, however, saw the aims and the scope of the above treaty being congenial to their declared interests, which were protection of language rights for Russian speakers (specifically). Thus, it should come as no surprise that the fact that the ECRML aims to promote the comprehensive protection of languages, whereby the protection of some languages ought not to be "to the detriment of the official languages and the need to learn them" (Council of Europe, 1992: $2)$, was lost on the above elites.

The Communists began to work (systematically) on the bill on the ECRML ratification only in 1999 (Alekseev, 2008: 60). Arguably, the radical Russian-speaking elites in Ukraine fathomed what seemed to have fallen into their hands still later.

The parliament passed the bill on the ECRML ratification in winter 1999. The Constitutional Court, however, abrogated this (adopted) bill on procedural grounds in summer 2000-which were Kuchma's apparent failure to sign the bill into law. Instead this bill was signed by the Speaker of Parliament, which turned out to be not an entirely correct process (see, for example, Arel, 2002: 233).

In the meantime, the Ukrainian governing elites adopted the special policy directive aimed at facilitating the further expansion in the use of the Ukrainian language in policy domains which had run the gamut from theatres to sports. ${ }^{54}$ For their part the town/ region councils or parliaments in the eastern and southern regions of Ukraine called for adopting resolutions that would grant the Russian language official status. At the same time, however, not everyone adopted this political attitude. For instance, then Deputy Speaker of Parliament Viktor Medvedchuk-the Russian-born Ukrainian oligarch with ethnically Ukrainian roots-argued that the above hypothetical resolutions would have no jurisdictional force ${ }^{55}$ (Medvedchuk is a lawyer by profession.)

The parliament resumed the (final) debate on the ratification of the ECRML in early 2003. At that time Kuchma made a veiled threat to submit to the parliament that particular version of the ECRML which the Communists found most repulsive to them. ${ }^{56}$ Namely, this version of the ECRML excluded Russian along with the several other (minor) languages from the bill on the treaty's ratification. As with the Constitution in 1996, the Communists caved in. So they supported in the parliament that particular version of the ECRML which Kuchma favoured. ${ }^{57}$ Namely, this version of the ECRML aimed to place Russian in an equal position vis-à-vis the several other languages of national minorities in the bill on the ECRML ratification. In this way, the bill on the ECRML ratification was passed in spring 2003 by a lop-sided 249-10 vote due to the active support by the cornered Communists. (The Communists or the mainstream Russian speakers of course favoured that particular version of the ECRML which was like the 1999 version of this treaty. Namely, this version of the ECRML laid down the particular threshold in terms of the size of the population in any given region or locality at which the Russian language would be qualified to receive official status, for example, 20 percent; this had been the benchmark in the 1999 version of the ECRML) (Kulyk, 2002: 112; Alekseev, 2008: 60, 84-85).

To conclude, it seems to be the case that the radical Russianspeaking elites in Ukraine ratcheted up their demands for de jure bilingualism because they had been culturally predisposed to do thus. Languages use assumed a mantle of state administered protection. 
Sociological change in Ukrainian polity owing to a certain politics comes into view.

Phase three: "On the offensive". The Orange Revolution in Ukraine in 2004 catapulted to power head of Our Ukraine Viktor Yushchenko, who was the major political opponent-in the above revolution-of Viktor Yanukovych. In turn, Yanukovych headed the Party of Regions, whose program included the demand for de jure bi-lingualism.

The ascension of Yushchenko to power was followed by the reenergized attempts of the state to facilitate the greater use of the Ukrainian language in the certain official realms (for example, state-funded education, mass media and justice) ${ }^{58}$ Given this, some town/region councils in the eastern and southern regions of Ukraine organized themselves in protest. Yet, not everyone adopted this political attitude. For instance, then-Speaker of parliament Volodymyr Lytvyn, who was no enemy of the Russian language though neither a strong supporter of it, called on the elites in Ukraine not to politicize the issue of the protection of language rights for national minorities (and, particularly, Russian speakers) on the eve of the 2006 parliamentary elections. ${ }^{59}$ Arguably more puzzlingly still, fluent Ukrainian speaker Medvedchuk argued in favour of laying aside grand debates about the status of the Russian language in Ukraine; focusing on the practical aspects of the use of the Russian language in Ukraine; and, last not least, making at least the token gesture toward the apparent salient need of Ukrainian speakers for state-guaranteed protection of their own language rights. ${ }^{60}$ (The above political attitude was adopted by a handful of individuals in Ukraine.) ${ }^{61}$

In the meanwhile, the Yushchenko-led coalition showed signs of fracture, because of an ongoing conflict between Yushchenko and then Prime Minister Yulia Tymoshenko. (In part, the above conflict boiled down to the clash between the two different persons) (Wilson, 2009: 323-25).

To further complicate matters, the foreign ministry delivered to the CE in fall 2005 the so-called instrument of ratification-which had been a requisite condition for completion of the formal procedure of the ECRML adoption in Ukraine. At this time, the Party of Regions drew upon the ECRML to press the possibility of granting the Russian language official (or "special") status.

The elections brought a big influx of the deputies from the Party of Regions to the town/region councils in some regions of Ukraine. The latter then called-at the prodding of the Progressive Socialist Party of Ukraine-for granting the Russian language official (or regional) status based on the (officially) enacted ECRML. ${ }^{62}$ Specifically, between the spring and summer of 2006, the town/region councils in some regions of Ukraine passed in a flurry of activity more than a dozen of resolutions aimed at granting the Russian language such status (Kolesnichenko and Bortnik, 2011: 231-33).

Then, with the coalitional crisis deepening, Yushchenko gave in and nominated Yanukovych for the post of prime minister. ${ }^{63}$ In a sense, with this step Ukraine came back to a status quo which existed at the time of the Orange Revolution, Yushchenko's assurances to the Ukrainian electorate to the contrary notwithstanding. ${ }^{64}$ For her part Tymoshenko faced no other option than to bide her time.

To conclude, the mainstream Russian-speaking elites in Ukraine escalated their demands for de jure bi-lingualism, in no small part because they saw them being legitimate. Languages use entered politics proper.

Phase four: The pyrrhic victory-for the Russian speakers. The grand Ukrainophone and Russophone coalition was founded based on the National Unity Pact, which provided for the same mode of the protection of language rights for Russian speakers as the Constitution (that is, all-round protection that excluded the formal regulation of the use of the Russian language in Ukraine). Soon after the formation of the above coalition in 2006, however, some deputies from Our Ukraine began to defect to the Party of Regions. (There is more than apparent evidence of the proposition that those deputies who defected to the Party of Regions, had been induced to do so through the promise of portfolios as well as bribery.) ${ }^{65}$ Seeing this, Yushchenko was horrified and called early parliamentary elections in fall 2007.66

However, the same old team which included erstwhile "Orange" allies threatened anew to run aground on the shoals of the long-running conflict between Yushchenko and (then Prime Minister) Tymoshenko. In fall 2008, it just happened that the Party of Regions and the Yulia Tymoshenko Bloc (BYuT) joined hands in order to trim the presidential powers of Yushchenko. It was in this political context that the above (estranged) political forces voted in fall 2008 in the first reading on a certain civil-service law which obliged civil servants or bureaucrats in some regions of Ukraine to be able to speak in the Russian language while discharging official duties. Tymoshenko faced a barrage of biting criticisms from the Ukrainian-speaking elites over the act of near treason. ${ }^{67}$ Tymoshenko then backpedaled, and pledged her loyalty to the protection of the Ukrainian language as the country's sole official language. ${ }^{68}$ In this way the counter-alliance between the BYuT and the Party of Regions proved short-lived (the centripetal prodding of an ongoing world economic recession notwithstanding).

The Yushchenko-led coalition survived until the 2010 presidential elections in Ukraine. At these elections, Yanukovych promised to the Russian-speaking constituencies that as President he would strive for having two official languages in Ukraine, namely Ukrainian and Russian, and staked his claim on the ECRML. ${ }^{69}$ However, the Party of Regions-upon having won in the above elections-called for taking a "tolerant" position in the issue-area of the protection of language rights for Russian speakers. ${ }^{70}$ Further, some members of the Party of Regions went so far as to disavow the Crimean parliament's decision-made in the wake of the elections-to grant the Russian language official (or regional) status based on the (adopted) ECRML. ${ }^{71}$ (The above elites did thus owing to the fact that they had been, so to speak, sobered through the acquisition of power.) ${ }^{72}$ Yet the political attitude adopted by some members of the Party of Regions was in all probability genuine. For instance, native Ukrainian speaker Hanna Herman-who was the spokesperson of Yanukovychconsistently argued in favour of the bi-lingual Ukraine. ${ }^{73}$

On the eve of the 2012 parliamentary elections in Ukraine, the Party of Regions rammed through the law, which granted the Russian language official or special status. For their part, some Ukrainian speakers among the deputies went on hunger strikes in protest.

Following Yanukovych's removal from power, through popular protests, in winter 2014, the parliament abrogated the 2012 language law. At about the same time Yanukovych fled into exile in Russia. Russia, under Vladimir Putin, then started the contested military occupation of the Crimea. Given this, the interim head-of-state in Ukraine declined to sign the above counter-bill into law. In the next following stage, the Crimea crisis metamorphosed into the larger political conflict-whose broader implications for the Ukrainian statehood had, arguably, proved devastating. ${ }^{74}$ Russia, as the kin state of ethnic Russians in Ukraine, continued to be a powerful player in the politics of ethnicity in Ukraine.

To conclude, the radical Russian-speaking elites in Ukraine had won, seemingly uncontroversially, a Pyrrhic victory. Languages use was disconnected from practice. Macrosociological developments occur. 


\section{Conclusion}

My contention in this article has been that the (variable) behaviours of ethnic minority elites, in the Romania and Ukraine cases, were the function of elites' ideas or interpretative frames (rather than cost-benefit calculation in view of the salient apparent resources and constraints, like leverage). ${ }^{75}$ Empirically speaking, in Romania, moderate ethnic minority elites did not escalate their demands when structural explanation or theory would lead us to expect the contrary behaviours; whereas, in Ukraine, radical linguistic minority elites radicalized their demands in a manner which was, prima facie, not inconsistent with the expectations of structural explanation or theory. ${ }^{76}$ Further, the empirical analyses drew, in part, on the analytical distinction proposed by Parsons between the a-rational and irrational variants of ideationally driven action. Actors may well disobey some salient incentive or impediment, and they are bound to reap what they have sown; actors may well obey some salient incentive or impediment, and they are bound to reap what they have sown. The above distinction permitted me to arbitrate not how much ideational elements can matter in politics-I suspect that they matter much more than it has been possible to argue here-but to what degree their effects can be demonstrable.

Furthermore, I attempted to show through the examples of language politics in Romania and Ukraine that a politics of interethnic compromise offers the greater chance to bring about sought-after and possibly lasting changes in state policies towards vulnerable or disadvantaged groups, like national minorities. More needs to be said, in this concluding section, about the above dynamic.

Many a policymaker conceives of the interrelationship between the art of politics and political change in linear terms. That is to say, so the argument goes, the more political pressure one brings to bear on the powers that be, the higher the likelihood that the latter would give consent to a given, sought-after political change. The comparative analysis of ethnic politics in Romania and Ukraine shows that there might well be a curvilinear-rather than simply a linear-relationship between the sought-after goals or policy changes, on one hand, and tactics (or strategies), on the other. Consider the following two possibilities (one of which is hypothetical). In the first hypothetical scenario, vulnerable or disadvantaged groups come to exert, for whatever reasons, no significant influence on political change, and so the powers that be face little incentive to lend a hand to the realization of certain changes in policies toward those groups. In the second scenario, for which there is plenty of evidence from both Romania and Ukraine, vulnerable or disadvantaged groups bring to bear excessive or politically dangerous pressures for political change on the powers that be, and so a certain variant of backlash ensues. Hence it may be argued that the key task of vulnerable or disadvantaged groups-and some elites in Romania understand this very well indeed-is to find the course of action that would steer clear of the above extremes. Accordingly, the relationships, which have been partly brought to light here, are hypothesized to be curvilinear or bell curve-shaped. Other baselines may well provide corroborating, or refuting, data for the "bell-curve" hypothesis. Setting aside the contextual niceties in the Romania and Ukraine cases, I venture an opinion that such a hypothesis has a broad appeal.

\section{Notes}

1 There are three international treaties, or documents, which "embody" the norm of language rights for national minorities, namely, the Framework Convention for the Protection of National Minorities, the European Charter for Regional or Minority Languages-both of the latter treaties are of the Council of Europe (based in
Strasbourg) — and the (1998) Oslo Recommendations regarding the Linguistic Rights of National Minorities-the latter document is of the Organization for Security and Co-operation in Europe.

2 Stated in other terms, this article argues that we must pay attention to the role of agency in attempting to understand (or explain) the behaviour of vulnerable or disadvantaged groups such as national minorities.

3 À la Nicolas Malebranche (1997 [1674/75]), I have no other choice but to embrace the above proposition-or hypothesis-based on the evidence.

4 The official documentation pertains to that of international organizations, for example, the Council of Europe in Strasbourg. The interview sample includes 78 interviews (including 2 heads of state and several ministers). The interviews were conducted in the Russian, English and German languages. The interviews were recorded by the author. All interview subjects are anonymous. The author's command of a diverse set of languages arguably brings an interesting look into the events on hand.

5 By the above, I imply only that the status quo inherently has a conservative bias.

6 The origins of the moderate thinking, if you will, by the mainstream Hungarian elites in Romania must be sought in the fact that these elites 1) had been (politically as well as personally) close to the Romanian, post-1989, leadership and 2) had realized that autonomous or self-governing political arrangements, were unrealizable in areas in which the Romanian and Hungarian ethnic groups were (even to small degree) mixed.

7 Reuters News, "Hungarians in Romania Demand Equal Rights But Not Autonomy", 5 January 1990. Also, author's interview with a senior UDMR official, summer 2010 Bucharest.

8 Agence France Presse, "Moderates Win But Only Just at Hungarian Minority's 2nd Congress", 27 May 1991.

9 For example, Reuters News, "Budapest Says Hungarians in Romania Under Threat", 24 January 1995.

10 See Csergô (2002: 19-21) for an analysis of the interrelationship, in the first half of the 1990s, among the UDMR and the Romanian opposition parties.

11 The UDMR gave the ruling Romanian parties the comfortable majority in the parliament.

12 Agence France Presse, "Coalition Government Agreed in Romania", 6 December 1996.

13 BBC Summary of World Broadcasts, "Ethnic Hungarian Leader Rejects 'BucharestBudapest-Washington Axis”, 29 April 1997.

14 BBC Summary of World Broadcasts, "Ethnic Hungarian Leader Rejects 'BucharestBudapest-Washington Axis”, 29 April 1997.

15 Author's interview with a very senior diplomat, spring 2012, Budapest.

16 The above counties were the Harghita, the Satu Mare, and the Sălaj ones.

17 See, for example, Reuters News, "Romanian Education Row Reopens Ethnic Wounds", 16 December 1997.

18 Deutsche Presse-Agentur, "Hungarian Ethnic Minority Party Quits Romanian Coalition Government”, 30 September 1998.

19 The above hypothetical university was called the Petőfi-Schiller university.

20 See, for example, Rompres, "Frontal Attack of Ethnic Hungarian Party Radicals", 15 February 1999

21 RFE/RL Newsline, "Hungarian Minority Content with Romanian Education Law", 1 July 1999.

22 RFE/RL Newsline, "Romania's UDMR to Enter a Governmental Coalition?" 21 December 2001.

23 RFE/RL Newsline, "Rift Surfaces in Hungarian Minority Party Leadership", 22 January 2001.

24 RFE/RL Newsline, "Rift Surfaces in Hungarian Minority Party Leadership", 22 January 2001.

25 WMRC Daily Analysis, "Ethnic-Hungarian Party Agrees to Extend Working Agreement with Romanian Government”, 21 February 2003.

26 RFE/RL, "Romania: Law Allows Use of Minority Languages in Public Administration”, 4 May 2001.

27 BBC Monitoring European-Political, "Romania's Hungarian Leader Calls for Bilateral Talks on Status Law", 27 June 2001.

28 Rompres, "UDMR Leader Says His Party Has Not Proposed 'Co-Sovereignty' in Transylvania”, 7 September 2001. The above (documented) viewpoint of Markó was also corroborated by one member of UDMR. Interview, Satu Mare, Summer 2014

29 RFE/RL Newsline, “Romanian UDMR to Form 'Civic-Christian' Faction”, 8 February 2002.

30 World News Connection, "Romanian Press Reports on Negative Reactions to Forum of UDMR", 3 June 2003.

31 Interview, Bucharest, Summer 2010

32 See, for example, BBC Monitoring European, "Romanian Hungarian Party Dissatisfied with Bill on Minority Rights", 25 April 2005.

33 BBC Monitoring European, "Romanian Hungarian Party Dissatisfied with Bill on Minority Rights", 25 April 2005.

34 DIVERS Bulletin, "Statute of the Minorities Can Bring About a More Serious Crisis Within the Coalition", 14 November 2005.

35 Rompres, "We Do Not Want Romania to Establish Super-Standards for Minorities', Says PD Emil Boc”, 7 December 2005. 
36 DIVERS Bulletin, “UDMR Not Be Nobody's Adjutant', Hungarian Leader”, 10 July 2006.

37 Rompres, "The Hungarian Democratic Union of Romania (UDMR)..." 27 March 2006.

38 For example, DIVERS Bulletin, "Referendum on Autonomy Finalized in 25 Towns in Covasna Sfintu Gheorghe", 2 October 2006.

39 DIVERS Bulletin, "The Hungarians' Reconciliation Party Postponed", 14 July 2008. 40 DIVERS Bulletin, “Autonomy, Main Focus of Ethnic Hungarians' Campaign”, 25 November 2007.

41 Interview, Bucharest, Summer 2010.

42 As one informed observer put it, Tókés himself was no longer a welcome guest at an anniversary of the 1989 revolution in the far-western Romanian town of Timisoara. Confidential source. (Tókés himself risked his life whilst igniting the above revolution for the sake of a democratic Romania and for the sake of the future of Hungarians in Romania) (see, for example, Brubaker et al., 2006: 119-22).

43 It bears notice that leaders, like Tókés, are viewed as being maverick and radical by the majority of EP members. Confidential source.

44 The Russian-speaking elite in Ukraine is highly heterogeneous as regards the latter's official party affiliation. Nevertheless, the goal of granting the Russian language official status can be said to be important or salient to all these Russian-speaking elites.

45 This is a variation on Erich Maria Remarque's "All Quiet on the Western Front". (No parallel, therefore, should be drawn with the current political events in Ukraine.)

46 The independence referendum was held in Ukraine on 1 December 1991.

47 Ethically speaking, Ukraine had had to roll back the Sovietization of Ukrainian culture.

48 Confidential source.

49 The origins of the radical thinking, if you will, by the mainstream Russian-speaking elites in Ukraine must be sought in disincentives facing Russian-speakers in general in a Soviet Ukraine-to accommodate the language-use by Ukrainian-speakers in general in a Soviet Ukraine.

50 BBC Monitoring Service: Former USSR, "Leonid Kuchma Delivers Election Address on Ukrainian Television”, 23 June 1994.

51 Article 10 of the Ukrainian Constitution lays down the sole official status of the Ukrainian language. Further, Article 10 states that-"Free development, use, and protection of Russian and other languages of national minorities of Ukraine shall be guaranteed in Ukraine". See http://www.legislationline.org/documents/action/popup/ id/16258/preview, accessed 9 June 2017.

52 Kelley (2004: 172) "dismiss[es] the effect of homeland explanations as direct explanatory factors for changes in ethnic policy". However, kin-states, like Russia in the Ukraine case, exercise enormous influence upon the political behaviour of ethnic minority leaders. To illustrate such a dynamic, consider the "special" relationship between Russian nationalists from Ukraine and former mayor of Moscow Yury Luzhkov, or the "special" relationship between Hungarian integrationists from Romania and the Hungarian Socialist Party in Hungary.

53 Anonymous interviews.

54 RFE/RL Reports, “Russia Afraid of Ukraine's De-Russification?” February 15, 2000.

55 Itar-Tass, "Ukraine Parliament Leader Opposes Raising Status of Russian", 10 November 2000.

56 The Current Digest of the Post-Soviet Press, "Russians Deemed an Ethnic Minority", 9 July 2003.

57 The Current Digest of the Post-Soviet Press, "Russians Deemed an Ethnic Minority", 9 July 2003.

58 See, for example, Itar-Tass, "Ukrainian Language Declared Obligatory at Ukrainian Courts", 1 September 2005; Christian Science Monitor, "Ukrainian vs. Russian Language: Two Tongues Divide Former Soviet Republic", 15 March 2010.

59 Interfax-Ukraine, "Lytvyn Urges Caution in Tackling Issue of Russian Language in Ukraine", 6 October 2005.

60 BBC Monitoring Ukraine \& Baltics, "Ukrainian Opposition Party Seeks Defence of Russian Language", 3 March 2005.

61 One informed anonymous interview subject corroborated the above proposition

62 Confidential source.

63 Associated Press, "Yushchenko Nominates Orange Revolution Foe Yanukovych to Be Premier", August 2, 2006

64 Associated Press, "Yushchenko Nominates Orange Revolution Foe Yanukovych to Be Premier", 2 August 2006.

65 Confidential source.

66 For example, Itar-Tass, "Yushchenko Urges Parties to Choose Priorities for Consolidation", 7 July 2007.

67 See, for example, Interfax-Ukraine, "Baloha Says BYT Helping to Secure New Status for Russian Language”, 22 September 2008.

68 Interfax-Ukraine, "Baloha Says BYT Helping to Secure New Status for Russian Language", 22 September 2008

69 See, for example, BBC Monitoring Ukraine \& Baltics, "Ukrainian Opposition Leader Vows "Comfortable Conditions" for Russian Language", 5 September 2009.

70 RIA Novosti, "Ukraine Would Be Split by Referendum on Russian Language - MP", 23 February 2010

71 Interfax-Ukraine, "Regions Party Lawmaker Slams Crimea's Decision to Use Russian as Regional Language", 28 May 2010.
72 Or, to state it otherwise, the victorious Russian-speaking elites felt an obligation to speak for an entire Ukraine.

73 For example, Ukrainian News, "MP Herman (Regions Party) Slams Donetsk City Council Secretary Levchenko for His Statements About Languages", 22 February 2007.

74 My readers will know the main lines of political or military or transborder conflict which unfolded in the wake of the contested military occupation of the Crimea by Russia in 2014

75 Sheri Berman (see 1998, chapter 2) elaborates on, and argues for, why it is scientifically sound or valid to study separately "ideas" as dependent and independent variables. In turn, Parsons $(2002,51)$ gives a succinct statement or argument with regard to the above: "Psychological or historical factors may help explain why actors came to hold certain ideas, but neither factor invalidates the claim that subjective ideas are now causing variation in behavior".

76 Critics may suggest that ethnic minority elites in Romania and Ukraine behave the way they do out of concerns about the need to placate their electorate. However, the electorate-based counter-argument has holes. Consider the case of interethnic marriages, in the Romania and Ukraine cases. It is non-controversial that in the latter Ukrainians and Russians are considerably more intermingled than are Romanians and Hungarians in the former. It would not be far-fetched then to argue that a politics of interethnic compromise might have after all found more fertile soil in Ukraine than Romania-bracketing the presence of the given ideational elements (cf. Stepan, Linz, and Yadav 2011: 188)

\section{References}

Alekseev V (2008) Begom ot Evropy? Kto $i$ kak protivodeistvuiet $v$ Ukraine realizatsii Evropeiskoi khartii regional'nykh iazykov ili iazykov men'shinstv [We're Forsaking Europe, Aren't We? The "Who" and the "How" of Attempts, in Ukraine, to Forestall the Implementation of the European Charter for Regional or Minority Languages]. Fakt: Kharkiv, Ukraine.

Anderson B (1983) Imagined Communities: Reflections on the Origin and Spread of Nationalism. Verso: London.

Andriescu M (2009) Identity politics under national communist rule. The Rhetoric manifestations of Nicolae Ceauşescu's 'nationality policy' in 1970 s Romania. Studia Politica. Romanian Political Science Review; 9 (1): 105-118.

Arel D (1995) Ukraine: The temptation of the nationalizing state. In: Tismaneanu V (ed). Political Culture and Civil Society in Russia and the New States of Eurasia. M.E. Sharpe: Armonk, NY.

Arel D (2002) Interpreting 'nationality' and 'language' in the 2001 Ukrainian Census. Post-Soviet Affairs; 18 (3): 213-249.

Bates RH (1981) Markets and States in Tropical Africa: The Political Basis of Agricultural Policies. University of California Press: Berkeley, CA.

Berk G (1994) Alternative Tracks: The Constitution of American Industrial Order, 1865-1917. Johns Hopkins University Press: Baltimore, MD.

Berman S (1998) The Social Democratic Moment: Ideas and Politics in the Making of Interwar Europe. Harvard University Press: Cambridge, US.

Biernacki R (1995) The Fabrication of Labor Germany and Britain, 1640-1914. University of California Press: Berkeley, CA.

Blyth M (2003) Structures do not come with an instruction sheet: Interests, ideas, and progress in political science. Perspectives on Politics; 1 (4): 695-706.

Brubaker R (1996) Nationalism Reframed: Nationhood and the National Question in the New Europe. Cambridge University Press: New York.

Brubaker R, Margit F, Jon F and Liana G (2006) Nationalist Politics and Everyday Ethnicity in a Transylvanian Town. Princeton University Press: Princeton, NJ.

Cornell SE and Hartmann D (2007) Ethnicity and Race: Making Identities in a Changing World, 2nd ed., Pine Forge Press, an Imprint of Sage Publication: Thousand Oaks, CA.

Council of Europe. (1992) European Charter for Regional or Minority Languages; ETS No. 148. Council of Europe: Strasbourg, France.

Csergó Z (2002) Beyond ethnic division: Majority-minority debate about the postcommunist state in Romania and Slovakia. East European Politics \& Societies; 16 (1): 1-29.

Csergo Z (2007) Talk of the Nation: Language and Conflict in Romania and Slovakia. Cornell University Press: Ithaca, NY.

Deets S and Stroschein S (2005) Dilemmas of autonomy and liberal pluralism: Examples involving Hungarians in central Europe. Nations and Nationalism; 11 (2): 285-305.

Dobbin F (1994) Forging Industrial Policy: The United States, Britain, and France in the Railway Age. Cambridge University Press: New York.

Gallagher T (1995) Romania after Ceauşescu: The Politics of Intolerance. Edinburgh University Press: Edinburgh, UK.

Goldstone JA (1991) Revolution and Rebellion in the Early Modern World. University of California Press: Berkeley, CA.

Gurowitz A (1999) Mobilizing international norms: Domestic actors, immigrants, and the Japanese state. World Politics; 51 (3): 413-445.

Hollis M and Lukes S (eds) (1982) Rationality and Relativism. MIT Press: Cambridge, US. 
Horváth I (2002) Facilitating Conflict Transformation: Implementation of the Recommendations of the OSCE High Commissioner on National Minorities to Romania, 1993-2001. Working Paper (8). Hamburg, Germany: Centre for OSCE Research.

Jenne EK (2007) Ethnic Bargaining: The Paradox of Minority Empowerment. Cornell University Press: Ithaca, NY.

Keck ME and Sikkink K (1998) Activists beyond Borders: Advocacy Networks in International Politics. Cornell University Press: Ithaca, NY.

Kelley JG (2004) Ethnic Politics in Europe: The Power of Norms and Incentives. Princeton University Press: Princeton, NJ.

Klotz A (1995) Norms in International Relations: The Struggle against Apartheid. Cornell University Press: Ithaca, NY.

Kolesnichenko V and Bortnik R (2011) Evropeiskaia khartiia regional'nykh iazykov ili iazykov men'shinstv: Problemy implementatsii v Ukraine [The Difficulties in the Implementation of the European Charter for Regional or Minority Languages in Ukraine]. Zolotyie Vorota: Kiev, Ukraine.

Kulyk V (2002) Revisiting a Success Story: Implementation of the Recommendations of the OSCE High Commissioner on National Minorities to Ukraine, 1994-2001. Working Paper (6). Hamburg, Germany: Centre for OSCE Research.

Laitin DD (1998) Identity in Formation: The Russian-Speaking Populations in the Near Abroad. Cornell University Press: Ithaca, NY.

Legro JW (1997) Which norms matter? Revisiting the "failure" of internationalism. International Organization; 51 (1): 31-63.

Malebranche N (1997 (1674/75)) The Search After Truth. Cambridge University Press: New York

Mearsheimer JJ (1990) Back to the future: Instability in Europe after the cold war. International Security; 15 (1): 5-56.

Moore B Jr (1966) Social Origins of Dictatorship and Democracy: Lord and Peasant in the Making of the Modern World. Beacon Press: Boston, MA.

Parsons C (2002) Showing ideas as causes: The origins of the European Union. International Organization; 56 (1): 47-84.

Parsons C (2007) How to Map Arguments in Political Science. Oxford University Press: New York.

Reddy WM (1987) The Rise of Market Culture: The Textile Trade and French Society, 1750-1900. Cambridge University Press: New York.

Risse T, Ropp SC and Sikkink K (eds) (2013) The Persistent Power of Human Rights: From Commitment to Compliance. Cambridge University Press: Cambridge, US.

Shevel O (2009) The politics of citizenship policy in new states. Comparative Politics; 41 (3): 273-291.

Skocpol T (1979) States and Social Revolutions: A Comparative Analysis of France, Russia, and China. Cambridge University Press: New York.

Stepan AC, Linz JJ and Yadav Y (2011) Crafting State-Nations: India and Other Multinational Democracies. Johns Hopkins University Press: Baltimore, MD.

Stepanenko V (2003) Identities and Language Politics in Ukraine: The Challenges of Nation-State Building. In: Daftary F and Grin F (eds). Nation-Building, Ethnicity and Language Politics in Transition Countries. Open Society Institute: Budapest, Hungary.

Stewart S (2001) Autonomy as a mechanism for conflict regulation? The Case of Crimea. Nationalism and Ethnic Politics; 7 (4): 113-141.

Swidler A (1986) Culture in action: Symbols and strategies. American Sociological Review; 51 (2): 273-286.
Van Houten P (1998) The role of a minority's reference state in ethnic relations. European Journal of Sociology; 39 (1): 110-146.

Waters T (1995) Towards a theory of ethnic identity and migration: The Formation of ethnic enclaves by migrant Germans in Russia and North America. The International Migration Review; 29 (2): 515-544.

Wilson A (1996) Ukrainian Nationalism in the $1990 \mathrm{~s}$ : A Minority Faith. Cambridge University Press: New York.

Wilson A (2009) The Ukrainians: Unexpected Nation, 3rd ed., Yale University Press: New Haven, CT.

Wolczuk K (2000) History, Europe and the 'National Idea': The 'official' narrative of national identity in Ukraine. Nationalities Papers; 28 (4): 671-694.

\section{Data availability}

Data sharing is not applicable to this article as no datasets were generated or analysed during the current study.

\section{Acknowledgements}

The author would like to thank Dylan Bennett, Chris Donoghue, Reinhard Heinisch, István Horváth, Elizabeth Kier, Ronald Mitchell, Craig Parsons, Mykola Riabchuk, Susan Stewart, and Till Weber for their valuable comments. An earlier version of this paper was presented at an annual meeting of the Western Political Science Association in 2012, Portland, OR. Support for this research was generously provided by the University Association for Contemporary European Studies in conjunction with the European Commission, the Gilchrist Educational Trust, the Hungarian Scholarship Board (MÖB), and the monthly research stipend administered by the New Europe College in Bucharest (in 2014). The remaining errors are the author's.

\section{Additional information}

Competing interests: The author declares that there are no competing interests.

Reprints and permission information is available at http://www.palgrave-journals.com/ pal/authors/rights_and_permissions.html

How to cite this article: Fedotov E (2017) Ideas, structures, and the (un)conventional politics of minority rights in Romania and Ukraine. Palgrave Communications. 3:17052 doi: $10.1057 /$ palcomms.2017.52

Publisher's note: Springer Nature remains neutral with regard to jurisdictional claims in published maps and institutional affiliations.

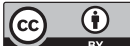

This work is licensed under a Creative Commons Attribution 4.0 International License. The images or other third party material in this article are included in the article's Creative Commons license, unless indicated otherwise in the credit line; if the material is not included under the Creative Commons license, users will need to obtain permission from the license holder to reproduce the material. To view a copy of this license, visit http://creativecommons.org/licenses/by/4.0/

(C) The Author(s) 2017 